\title{
PARTISIPASI ULAMA DALAM PENDIDIKAN ISLAM DAN PANDANGANNYA TENTANG PENYELENGGARAAN MADRASAH DI INDONESIA DEWASA INI
}

\author{
Oleh: Abd. Kadir Ahmad
}

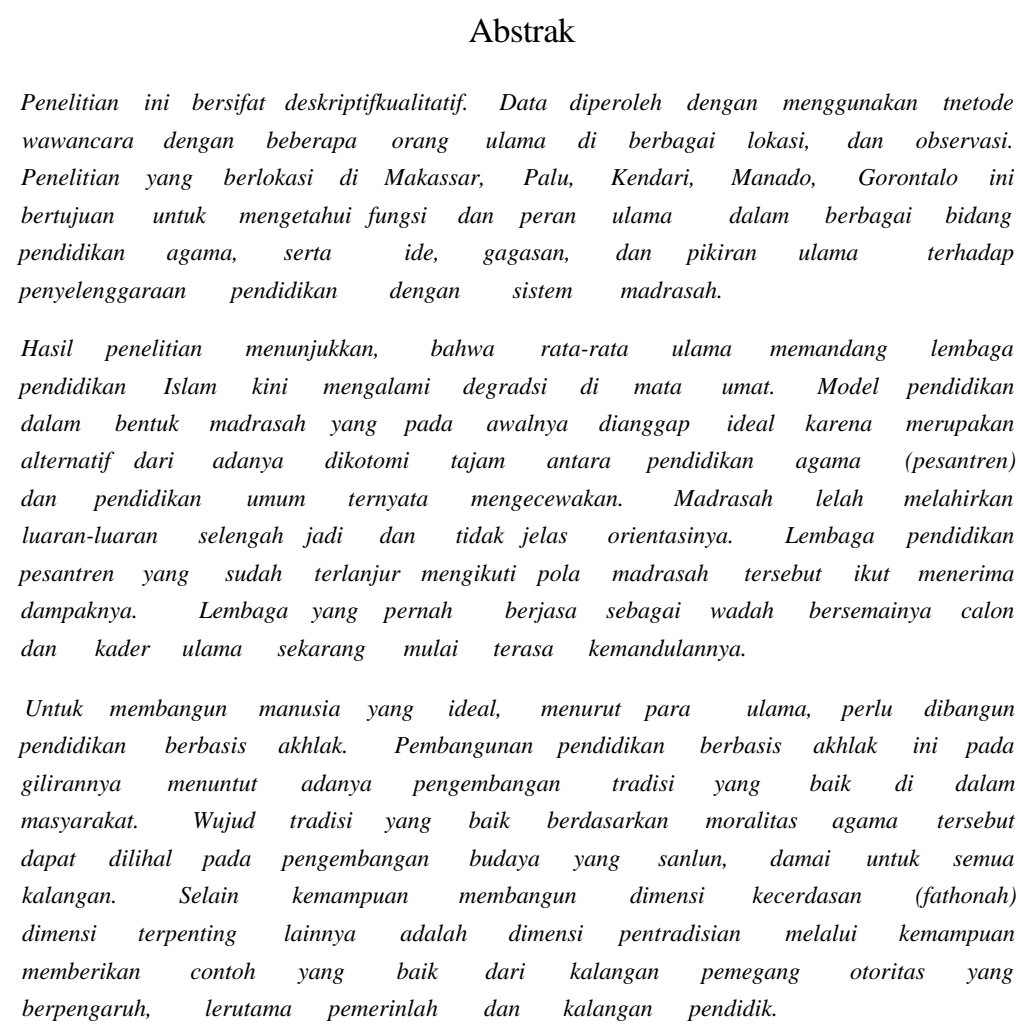

\section{PENDAHULUAN}

Dalam Islam, ulama diyakini sebagai pewaris para Nabi (waratsah al-Anbiya), bertugas meneruskan fungsi Nabi sebagai $d a^{\prime} i$ menyeru manusia kepada (menyembah) Allah (QS. 33 : 46). Dua warisan utama yang harus diemban oleh ulama adalah (melestarikan ajaran) Alquran dan Hadits. Ulama, dengan demikian, merupakan suatu kelas ahli yang bertugas menafsirkan Alquran, menjadi jiwa dan hati ortodoksi Islam, seorang ahli hukum yang sekaligus juga seorang guru yang telah menggariskan bentuk dan banyak menentukan isi Islam (Geertz 1981). 
Oleh karena ilmu dan otoritas yang dimilikinya, maka ulama menempati posisi sebagai elit sosial dalam sistem masyarakat Islam (Lapidus, 1989). Sebagai elit sosial, ulama memiliki fungsi yang luas tidak terbatas pada wilayah keagamaan saja, tetapi juga pada bidang-bidang lainnya (Dhofier, 1994). Ulama, dengan demikian, bukan saja sebagai kelompok ahli hukum Islam yang secara tradisional berfungsi sebagai muballig, guru, tetapi juga tempat bertanya umat Islam dalam menghadapi berbagai masalah (Hirokoshi, 1987).

Peran sentral ulama seperti itu membutuhkan pengkajian khususnya fungsi dan gagasan mereka dalam pengembangan pendidikan Islam dan khazanah keagamaan yang mereka hasilkan. Ulama di sini dilihat sebagai ahli agama Islam yang menjadi rujukan masyarakat dalam berbagai persoalan keagaman atau seseorang yang oleh masyarakat disebut ulama dengan sebutan yang berbeda-beda, misalnya gurutta di Sulawesi Selatan atau kyai di tempat lain. Fungsi ulama dimaksudkan sebagai status mereka dalam lembaga-lembaga pendidikan Islam. Sedangkan peran ulama adalah aktivitas yang dilakukan ulama sebagai akibat dari fungsi tersebut. Pendidikan Islam diartikan sebagai jenis pendidikan yang pendirian dan penyelenggaraannya didorong oleh hasrat dan semangat cita-cita untuk mengejawantahkan nilainilai Islam, baik yang tercermin dalam nama lembaganya maupun dalam kegiatan-kegiatan yang diselenggarakan.

Secara kelembagaan pendidikan Islam disini adalah pesantren atau madrasah, atau perguruan tinggi bercirikan Islam (Zarkowi Soejoeti, 1986). Khasanah keagamaan adalah karya tulis yang dihasilkan oleh ulama baik berupa buku, diktat, makalah, naskah ceramah/khotbah, artikel di majalah/ surat kabar/penerbitan lain; tercetak atau tidak.

Fokus penelitian ini diarahkan pada (1) patisipasi ulama dalam bidang pendidikan Islam, dan (2) bagaimana gagasan ulama tentang penyelenggaraan pendidikan Islam, khususnya sistem madrasah.

Penelitian ini bertujuan mengungkap (1) fungsi dan peran ulama dalam berbagai bidang pendidikan agama, (2) ide, gagasan, pikiran, ulama tentang penyelenggaraan pendidikan dengan sistem madrasah.

Signifikansi ilmiah dari penelitian ini dapat memperkaya pemahaman tentang fungsi dan peran ulama dalam bidang pendidikan Islam. Signifikansi praktis berkaitan dengan kebutuhan memahami kembali fungsi dan peran ulama dan kebutuhan untuk melakukan penataan ulang berbagai kebijakan dalam sistem pendidikan agama di Indonesia.

Penelitian ini dilakukan di lima provinsi di Sulawesi yaitu Sulawesi Selatan, Sulawesi Tengah, Sulawesi Tenggara. dan Sulawesi Utara dan 
Gorontalo. Sasaran utama adalah ulama yang ada di ibukota provinsi yaitu Makassar, Palu, Kendari, Manado, Gorontalo. Cara pemilihan ulama dilakukan secara purposive berdasarkan kriteria keulamaan seperti disebutkan di atas, dan setelah mendapatkan masukan dari key informant, yakni Kepala Kanwil Agama atau Majelis Ulama Indonesia (MUI) setempat. Dengan teknik tersebut terjaring 14 orang ulama sebagai subyek penelitian ini.

Tabel 1: Daftar Ulama Kasus

\begin{tabular}{|c|c|c|}
\hline NO & NAMA ULAMA & PROVINSI/ DAERAH \\
\hline 1 & K.H.Muhammad Nur & Sulawesi Selatan / Makassar \\
\hline 2 & Prof.Dr.K.H.Sahabuddin & Sulawesi Selatan/Makassar \\
\hline 3 & Drs.K.H.Jamaluddin Amicn & Sulawesi Selatan/Makassar \\
\hline 4 & Drs.K.H.Harisah HS & Sulawesi Selatan/Makassar \\
\hline 5 & Drs. K.H.Busthamin Syarif & Sulawesi Selatan/Gowa \\
\hline 6 & Drs. KH.M.Arief Siraj Lc, & Sulawesi Tengah/Palu \\
\hline 7 & S.Saggaf Al-Jufri, MA & Sulawesi Tengah/Palu \\
\hline 8 & Drs.K.H.Ahmad Yamani & Sulawesi Tengah/Palu \\
\hline 9 & Drs.K.H.Khalilullah Ahmas, Lc & Sulawesi Utara/Manado \\
\hline 10 & Drs.H.Rizali Muhammad Noor & Sulawesi Utara/Manado \\
\hline 11 & Drs. Zainul Romiz Koesry, M.Ag & Gorontalo/Gorontalo \\
\hline 12 & Drs. Kaso' & Sulawesi Tenggara/Kendari \\
\hline 13 & Drs.H.Ryha Madi & Sulawesi Tenggara/Buton \\
\hline 14 & Drs.La Ode Muh.Anshari Idris & Sulawesi Tenggara/Buton \\
\hline
\end{tabular}

Pengumpulan data dilakukan melalui wawancara mendalam (indepth interviewing) yang masing-masing dilakukan oleh 14 orang peneliti. Teknik ini memungkinkan eksplorasi secara mendalam mengenai fungsi ulama. Untuk memudahkan jalannya wawancara terlebih dahulu disiapkan instrument berupa pedoman wawancara.

Analisis data dilakukan melalui kegiatan reduksi, penyajian, dan interpretasi data. Reduksi data dilakukan melalui mekanisme inklusi-eksklusi atau penyaringan data yang sesuai dengan fokus yang sudah terjabarkan ke dalam tema-tema atau sub tema penelitian. Penafsiran dilakukan dengan mengungkap hubungan yang terjadi dalam suatu statemen, antar statemen, antar faktor atau antar tema. 
Penelitian ini berhasil mengungkapkan betapa partisipasi ulama dalam bidang pendidikan Islam masih tetap bertahan. Hal ini dibuktikan dengan keterlibatan mereka baik sebagai pemilik yayasan, pembina, dan pimpinan pesantren, madrasah, atau bahkan perguruan tinggi. Meski demikian, keterlibatan mereka di dalam lembaga pendidikan berbasis keislaman tersebut tidak lagi sebagai pemegang otoritas tunggal. Hal itu disebabkan keharusan mengakomodir kebijakan pemerintah mengenai penataan lembaga pendidikan dalam bentuk madrasah (mulai dari tingkat Ibtidaiyah sampai Aliah) dengan perimbangan kurikulum 30 persen agama dan 70 persen umum.

Setelah hampir tiga dasawarsa diterapkan di Indonesia para ulama menilai sistem madrasah tersebut tidak membawa hasil yang diharapkan. Lulusan madarasah dinilai "setengah-setengah", tidak dapat menguasai agama dengan baik, dan juga tidak mampu bersaing dengan sekolah umum. Untuk itu, ulama merekomendasikan agar kurikulum madrasah ditinjau ulang, minimal pelajaran agama seimbang dengan pelajaran umum.

\section{TINJAUAN PUSTAKA Konsep Ulama}

Kata ulama disebutkan dua kali dalam Alquran, yaitu dalam Surah Fathir (35) : 28 dan Surah Asy-Syu'ara"(26): 197. Pada Surah Fathir. 28 disebutkan bahwa "sesungguhnya yang takut kepada Allah di antara hamba-hamba-Nya hanyalah ulama". Sementara, dalam Surah Surah AsySyu 'ara '(26): 197 disebutkan pengakuan ulama Bani Israil tentang kebenaran kandungan Alquran.

Berdasarkan kedua ayat tersebut, Shihab (1992) menyimpulkan pengertian ulama tidak hanya mengacu pada penguasaan ilmu agama melainkan juga ilmu umum; atau penguasaan pengetahuan tentang ayatayat Allah, baik yang bersifat kawniyyah maupun qur'aniyyah. Yang membedakan antara sarjana atau cendekiawan dengan ulama, menurut Shihab, tidak terletak pada bidang ilmunya melainkan pada apakah ilmu yang dimilikinya mengantar menusia kepada pengetahuan tentang kebenaran Allah, taqwa dan khasyyah (takut kepada-Nya) atau tidak.

Hal ini senada dengan pandangan Al-Baghdadi (1994), yang menggunakan istilah ulama untuk menyebutkan ahli-ahli di bidang ilmu syariat dan juga para ahli dalam bindang ilmu-ilmu logika dan eksperimental.

Pandangan yang berbeda dikemukakan oleh Abu Bakar Jabir Aljazairy (2001) yang mengidentifikasi ulama sebagai mereka yang menguasai, 
mengamalkan, dan menyebarluaskan ilmu agama. Mereka itulah orang-orang yang menjaga tegaknya agama Islam dan menjadi petunjuk bagi manusia yang lainnya. Mereka itulah yang diisyaratkan oleh Allah dalam firmanNya pada Q.S Fathir: 28; Q.S.Az-Zumar: 9, seperti disebutkan di atas, dan ayat-ayat lain seperti Q.S. Al-Ankabut: 43; dan Q.S. Ali Imran: 18.

Di Indonesia, pengertian ulama digunakan menurut pengertian khusus di atas. Pengertian khusus ini lebih kental lagi ketika setiap komunitas Islam menerjemahkan ulama ke dalam konteks lokal, seperti kyai di Jawa, ajengan di Jawa Barat, teungku di Aceh, tuan guru di Lombok, dan Gurutta di Sulawesi Selatan. Persentuhan dengan budaya lokal membuat ulama tidak dapat digeneralisir lagi. Setidaknya, setiap komunitas memiliki cara tersendiri untuk mengidentifikasi ulamanya masing-masing.

Menurut Dhofier, kyai pada dasarnya merupakan gelar yang diberikan oleh masyarakat kepada seorang ahli agama Islam yang memiliki atau menjadi pimpinan pesantren dan mengajar kitab-kitab klasik kepada para santrinya. Dhofier menyimpulkan bahwa, dengan kaitan yang sangat kuat dengan tradisi pesantren, gelar kyai biasanya dipakai untuk menunjuk ulama dari kelompok Islam tradisional. Kriteria ini lebih memperkaya kedua kriteria yang disebutkan di atas sehingga dapat disimpulkan bahwa kyai minimal harus memenuhi kriteria (1) pengusaan ilmu keislaman, (2) akseptabilitas publik, (3) memimpin pesantren dan (4) mengajar kitab klasik (kitab kuning).

Steenbrink (1994), memiliki kriteria sederhana mengenai kyai yaitu. seorang dapat disebut kyai karena ia diterima masyarakat sebagai kyai. karena orang datang minta nasehat kepadanya, atau mengiriinkan anaknya supaya belajar kepada kyai. Jadi, untuk menjadi kyai tidak ada kriteria formal seperti persyaratan studi, ijazah, dan sebagainya. Ia juga mengemukakan kriteria non-formal yang harus dipenuhi oleh seorang kyai besar, mengutip H.Aboebakar Atjeh, yaitu: (1) pengetahuannya, (2) kesalehannya, (3) keturunannya, dan (4) jumlah muridnya. Skema itu, menurut Steenbrink, sama dengan skema yang diberikan Vredenbregt, yaitu: (1) keturunan, (2) pengetahuan agama, (3) jumlah murid dan, (4) caradia mengabdikan diri dalam masyarakat.

Catatan penting perlu diberikan untuk berbagai skema di atas. Pertama, tidak ada di antara skema-skema tersebut yang mempersoalkan persyaratan bahwa seorang kyai harus seorang laki-laki. Kedua, faktor keturunan merupakan fenomena lokal dan bukan universal. Faktor keturunan memegang peranan berdasarkan alasan sosial bahwa kyai untuk pesantren tradisional mungkin anak dari kyai, atau kalau ayahnya bukan seorang kyai, mungkin salah seorang familinya seorang kyai, atau kakeknya dan seterusnya. 
Kesalehan seorang kyai dikaitkan dengan pengabdiannya yang total untuk mengajar agama tanpa kenal lelah dan tanpa menuntut bayaran. Ia harus memenuhi setiap permintaan untuk pergi ke desa atau kota untuk mengajar. Baginya, mengajar adalah satu pekerjaan yang baik, dan oleh karena itu dia tidak dibayar untuk pekerjaannya. Di samping mengajar, kyai masih harus bekerja di tempatnya sendiri untuk memenuhi nafkahnya dan melaksanakan semua kewajiban agama dan amalan-amalan sunnah.

\section{Fungsi dan Peran Ulama}

Menurut Shihab (1992), ada empat tugas atau peran utama yang harus dijalankan ulama sesuai dengan tugas kenabian. Pertama, menyampaikan ajaran-ajaran Islam. Kedua, menjelaskan ajaran-ajaran Islam. Ketiga, memutuskan perkara atau problem yang dihadapi masyarakat. Keempat, memberikan contoh pengamalan. Tugas ulama di atas bersifat normatif merupakan konsekuensi posisinya sebagai pewaris Nabi. Fungsi ulama, dengan demikian, adalah sebagai mubalig, pengajar, hakim dalam arti pengambil keputusan, dan teladan bagi pengikutnya.

Fungsi dan peran ulama mengalami transformasi sesuai kondisi zaman. Kelihatannya fungsi ulama pada zaman kerajaan dan kolonial menurut Benda dan Pijper adalah sebagai penghulu dan guru agama. Fungsi sebagai penghulu meliputi fungsi-fungsi (1) penasehat atau mufti, (2) hakim (qadli) (3) pemangku mesjid dan seluruh pegawai bawahannya; (4) pengurus dan pencatat pernikahan, perceraian, dan rujuk menurut hukum Islam; dan (5) pengawas pendidikan agama.

Pada perkembangan selanjutnya Horikoshi tidak melaporkan adanya fungsi birokrasi lagi sebagai penghulu melainkan lebih pada otoritas keilmuan dan pemimpin ibadah yaitu sebagai (1) pemangku masjid dan madrasah, (2) pengajar dan pendidik, dan (3) ulama sebagai ahli dan penguasa hukum Islam.

Saletore memasukkan dimensi politik sebagai salah satu fungsi ulama. Fungsi-fungsi tersebut adalah ulama sebagai (1) guru, (2) mubalig, (3) pegawai pemerintah, dan (4) Politisi. Ulama sebagai pegawai pemerintah biasanya berfungsi sebagai syaikhul Islam, qadhi, khatib, imam.dan guruguru dalam lembaga pendidikan pemerintah. 


\section{Kerangka Konseptual}

Ulama dalam studi ini dipandang sebagai kelompok ahli dalam bidang keagaman Islam. Sebagai kelompok ahli ulama merupakan jembatan antara Islam sebagai ajaran dan umat Islam. Instrumen yang digunakan oleh ulama untuk menjembatani kedua hal tersebut adalah pendidikan baik dalam arti formal maupun nonformal. Instrumen lain yang digunakan adalah lewat karya tulis.

Tujuan pendidikan itu sendiri dimaksudkan sebagai wadah untuk mencapai manusia ideal menurut Islam dan seterusnya masyarakat ideal. Sebagai prasyarat terbentuknya manusia dan masyarakat ideal tersebut, maka pendidikan Islam diharapkan dapat memberdayakan umat Islam agar mampu memainkan peran tertentu di dalam masyarakat dan bangsa Indonesia.

Sebagai instrumen untuk membentuk manusia seutuhnya (manusia ideal) dan baldatun thayyibah (masyarakat ideal), ulama kemudian memberikan penilaian terhadap peran lembaga pendidikan Islam, khususnya madrasah dan pesantren.

Wadah pengabdian ulama adalah di pemerintahan dan masyarakat. Dengan demikian ulama dapat diklasifikasi ke dalam ulama birokrasi dan ulama independen. Ulama independen kemudian dapat dirinci ke dalam ulama organisasi, ulama pesantren, ulama tarekat dan ulama bebas (tanpa lembaga).

Pada masa pemerintahan kerajaan ulama merupakan bagian dari birokrasi kerajaan dan menduduki fungsi kunci dalam struktur masyarakat Islam. Pada zaman kolonial dan revolusi banyak ulama terjun sebagai pejuang kemerdekaan. Pasca kemerdekaan ulama lebih banyak mengkonsolidasikan diri dalam gerakan pendidikan dan dakwah, baik sebagai pimpinan pondok pesantren atau madrasah, guru, khalifah suatu aliran tarekat, mubalig atau pembimbing calon-calon ulama melalui pengajian pendalaman bidang kajian tertentu (takhassus). Ulama juga berperan sebagai agen pembangunan, terutama dalam masa pemerintahan Orde Baru.

Selain menekuni bidang tugas tertentu baik sebagai pegawai negeri atau pendidik, ulamajuga memainkan peran sosial di masyarakat, terutama memberikan pelayanan terhadap kebutuhan upacara atau hajat masyarakat. Hajat masyarakat yang paling lazim adalah berkaitan dengan upacara siklus hidup, syukuran, peringatan hari-hari besar Islam, memimpin shalat dan mengurus masjid, infak, zakat dan shadaqah, pengobatan dan sebagainya. 


\section{KERANGKA KONSEPTUAL ULAMA DAN PENDIDIKAN}

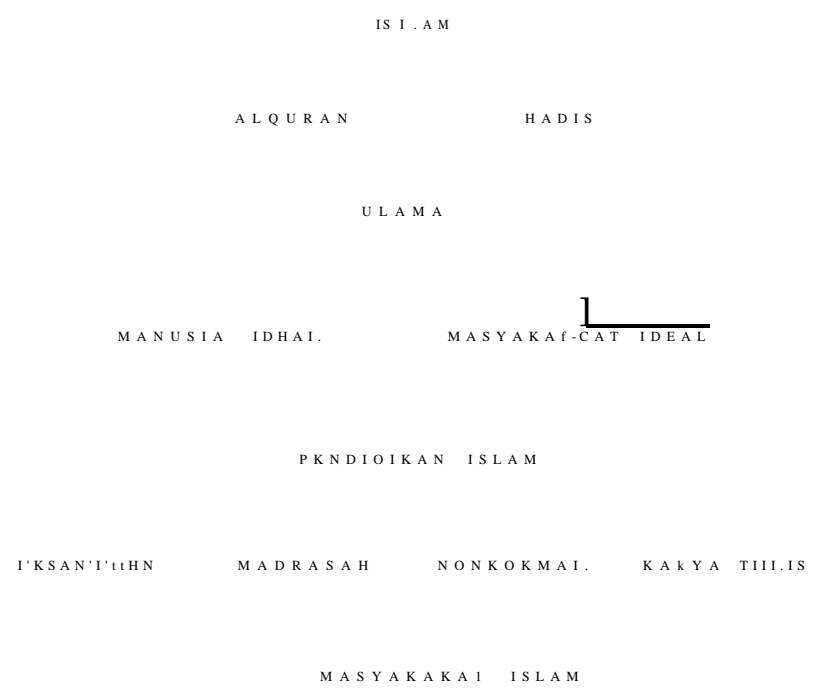

\section{III.TEMUAN PENELITIAN}

\section{A. Fungsi Ulama Dalam Pendidikan Islam}

Ulama adalah figur sentral dalam masyarakat Islam. Ia menjembatani ajaran Islam sebagaimana termaktub dalam kitab suci dan hadis Rasulullah serta kitab-kitab klasik peninggalan ulama terdahulu, kepada umat. Oleh karena itu, fungsi ulama identik dengan pendidik dalam arti luas. Ia mendidik masyarakat Islam melalui penyampaian ajaran Islam dan melalui contoh-contoh prilakunya. Semakin intens dan luas jangkauan pendidikan yang dilayani seorang ulama semakin besarlah ulama tersebut.

Penelitian ini menunjukkan besarnya peranan ulama dalam pendidikan formal keagamaan dan pendidikan nonformal. Dalam bidang pendidikan formal ulama berfungsi sebagai pendiri dan pimpinan pondok pesantren, pembina/pengajar madrasah, atau perguruan tinggi. Dalam bidang pendidikan nonformal ulama berfungsi sebagai pembina majelis taklim dan pengajian takliassus (pendalaman satu bidang tertentu). Ulamajuga berfungsi sebagai mubalig yang melayani kebututuhan masyarakat terhadap dakwah. Selain itu ulama juga pelayan yang memberikan layanan terhadap berbagai hajatan masyarakat.

Sejumlah faktor menjadi prasyarat dan berpengaruh terhadap fungsi dan peran ulama dalam pengembangan pendidikan Islam. Faktor-faktor tersebut adalah latar belakang lingkungan keluarga, faktor pendidikan, dan pekerjaan pokok ulama. Penelitian ini menunjukkan bahwa seseorang menjadi ulama antara lain karena didukung oleh lingkungan keluarga yang kondusif. 
Tabel 2: Fungsi Dan Peran Ulama

\begin{tabular}{|c|c|c|}
\hline NO & NAMA ULAMA & Fungsi Ulama dalam pendidikan \\
\hline 1 & K.H. Muhammad Nur & $\begin{array}{l}\text { Pendiri/pengasuh MD1A (Ma'hadud Dirasatil Islamiyah } \\
\text { Wal Arabiyah) Makassar, pengasuh pengajian } \\
\text { (takhassus), majelis taklim, da'i, pemimpin tarekatul } \\
\text { Muhammadiyah. }\end{array}$ \\
\hline 2 & Prof. Dr. KH. Sahabuddin & $\begin{array}{l}\text { Dosen IAIN Alauddin, pengasuh beberapa perguruan } \\
\text { tinggi swasta, Pimpinan Pondok Pesantren, pembina } \\
\text { majelis taklim, da'i dan pemimpin tarekat. }\end{array}$ \\
\hline 3 & $\begin{array}{l}\text { Drs.K.H.Jamaluddin } \\
\text { Amien }\end{array}$ & $\begin{array}{l}\text { Pesnsiunan Guru Agama, mantan Rektor, Pimpinan } \\
\text { Muhammadiyah Sulawesi Selatan, da'i }\end{array}$ \\
\hline 4. & Drs.KH.Harisah HS & $\begin{array}{l}\text { PNS, Pemilik/pimpinan ponpes An-Nahdlah Makassar, } \\
\text { da.i, pembina majelis taklim. }\end{array}$ \\
\hline 4 & Drs.K.H.Bustamin Syarif & $\begin{array}{l}\text { Pimpinan Ponpes Bahrul Ulum Gowa, da'i. pembina } \\
\text { majelis taklim Fastabiqul Khairat. }\end{array}$ \\
\hline 5 & Drs.H.Rizali Muh. Noor & $\begin{array}{l}\text { Kepala Ma'had Pondok Pesantren (Pondok Karya } \\
\text { Pembangunan) di Manado, Pembina LPTQ, TPA, Majlis } \\
\text { Taklim di samping berdakwah. }\end{array}$ \\
\hline 6 & $\begin{array}{l}\text { Drs.K.H.Khalilullah } \\
\text { Ahmas }\end{array}$ & Pengasuh Pondok Pesantren Putri As-Salam Manado \\
\hline 7 & Drs.K.H.Hasan Yamani & $\begin{array}{l}\text { PNS, pengasuh Madrasah DDI di Palu. Membina majelis } \\
\text { taklim dan dakwah di masyarakat. }\end{array}$ \\
\hline 8 & Drs.K.H.M. Arif Siraj, LC & $\begin{array}{l}\text { Tenaga pengajar (PNS) memimpin pembina pesantren AI } \\
\text { Istiqamah Ngatabaru, muballiq, aktif membina pengajian } \\
\text { Majelis Ta'lim. }\end{array}$ \\
\hline 9 & S. Saggaf Aljufrie, MA & $\begin{array}{l}\text { Ketua Utama Al-Khairat Palu, memberikan dakwah dan } \\
\text { pengajian di berbagai mesjid dan majelis-mejelis taklim }\end{array}$ \\
\hline 10 & Drs. Kaso & $\begin{array}{l}\text { PNS, pengasuh ponpes Al Munawwarah di Kabupaten } \\
\text { Kendari, di Kabupaten Kendari, da'I }\end{array}$ \\
\hline 11 & Drs. H. Ryha Madi & $\begin{array}{l}\text { Pe'nsiunan guru, membina panti asuhan, majlis taklim. } \\
\text { pembina pesantren, dan Yayasan Yaumi. }\end{array}$ \\
\hline 12 & Drs.Laode M.Anshari Idris & $\begin{array}{l}\text { pimpinan madrasah di Wangi-Wangi Buton, da'i, } \\
\text { membina majelis Taklim Zawawy di Bau-Bau. }\end{array}$ \\
\hline 13 & $\begin{array}{l}\text { Drs.Zainul Romiz Koesry, } \\
\text { M.Ag }\end{array}$ & $\begin{array}{l}\text { Dosen (PNS) di STAIN Gorontalo, pengasuh pondok } \\
\text { pesantren (Al-Falah), da'i. }\end{array}$ \\
\hline
\end{tabular}

Sejak kecil mereka dididik oleh orang tua mereka sendiri di dalam keluarga sebelum diserahkan kepada orang lain. Ayah atau ibu merekalah yang pertama-tama meletakkan dasar-dasar agama yang diberikan melalui pengenalan (pengajian dasar) Alquran. Sambil diajar mengaji mereka juga dibimbing melaksanakan ibadah-ibadah pokok terutama shalat. Setelah tamat mengaji di bawah bimbingan orang tua barulah mereka diserahkan kepada orang lain atau dimasukkan sekolah agama.

Menjadi ulama bukanlah sesuatu yang kebetulan. Mereka memiliki konsistensi pendidikan dalam bidang agama Islam sejak dini. Mereka pun tidak pernah berhenti belajar untuk memperdalam atau menyegarkan 
ilmunya. Mereka betul-betul pengamal ajaran Nabi: " tuntutlah ilmu mulai dari ayunan sampai hang lahat". Mereka memiliki kesadaran ilmu yang tinggi.

Secara formal ulama membutuhkan kemampuan pendidikan dasar. Ulama yang dimasa anak-anak hidup pada zaman pemerintahan Belanda biasanya belajar di Vervolg School (VVS). Sedangkan yang hidup di zaman kemerdekaan biasanya mengambil pelajaran dasar mereka di Sekolah Rakyat atau Sekolah Dasar. Setelah tamat sekolah dasar ada sebagian kecil ulama yang tetap meneruskan pendidikannya melalui jalur pendidikan umum, misalnya SMP dan SMA atau sekolah umum yang sederajat. Sambil belajar di sekolah umum ulama model ini menempuh pendidikan agama melalui sekolah diniah di sore hari atau belajar secara non-formal (pengajian halaqah) ke ulama-ulama tertentu.

Trend umum pola pendidikan ulama adalah setelah tamat sekolah dasar mereka kemudian mulai mengkhususkan pendidikannya di jalur sekolah agama. Umumnya pendidikan dasar keagamaan secara formal dimulai pada tingkat ibtidaiyah, kemudian di tsanawiyah atau PGA 4 tahun dan seterusnya aliyah atau PGA 6 tahun atau Sekolah Persiapan IAIN. Jalur pendidikan keagamaan di tingkat pendidikan tinggi di tempuh di IAIN atau Sekolah Tinggi Agama Islam.

Beberapa ulama mengenyam pendidikan di luar negeri, khususnya di Mesir dan Mekah. Mereka ini biasanya menyandang gelar "Lc" atau "MA", atau gelar tidak formal seperti "Al-Alimul Allamah" atau "Syekh" bagi lepasan pengajian-pengajian di Mekah. Di kalangan masyarakat masih berkembang pandangan, bahwa menuntut ilmu dari sumber ilmu pengetahuan Islam di Timur Tengah dipandang sebagai model pendidikan yang ideal dan diidamkan setiap calon ulama. Ulama yang berlatar belakang pendidikan Timur Tengah memiliki tempat khusus di antara ulama-ulama yang lain. Bersamaan dengan dukungan faktor lain, ulama yang dibesarkan di pusatpusat pendidikan di Mekah atau Mesir dianggap lebih berkualitas.

Kesamaan pola latar belakang pendidikan membuat ulama juga mengembangkan pola pendidikan yang relatif sama, yaitu pengembangan pendidikan melalui pendirian atau pengabdian pada lembaga pendidikan Islam. Semua ulama membina lembaga pendidikan Islam, baik dalam bentuk pesantren, madrasah atau perguruan tinggi. Selain membina lembaga pendidikan Islam, ulama juga membina majelis taklim (takhassus atau umum), melayani masyarakat di bidang dakwah, dan pelayanan-pelayanan hajatan warga masyarakat. 


\section{B. Pandangan Ulama Tentang Manusia Ideal}

Sebelum membahas tentang cita-cita pendidikan Islam terlebih dahulu perlu dikemukakan pandangan ulama tentang manusia ideal. Hal ini penting mengingat manusia ideal adalah gambaran ideal dari manusia yang menjadi cita-cita dalam pendidikan sebagai proses pembentukan pribadi dan masyarakat.

Ulama menggunakan beberapa konsep untuk menggambarkan manusia ideal, misalnya manusia yang baik atau manusia yang sempurna. Ulama melihat sifat dasar manusia ideal dapat dilihat pada akhlak, terutama pada aspek kemampuan seseorang mengendalikan diri dari segala macam perilaku tercela. Pada basis akhlak itulah berdiri kemampuan yang lain yaitu ketaatan melaksanakan perintah agama. Ulama juga menekankan perlunya aspek tradisi, bahwa Islam atau syariat selain bersumber dari Alquran dan Sunnah Nabi juga perlu dikembangkan tradisi keagamaan yang tergambar dalam budaya masyarakat yang etis dan bermoral berdasarkan etika dan moralitas Islam. Hal ini sudah menjadi tradisi dalam kehidupan yang dibangun oleh Nabi dan para sahabat serta generasi selanjutnya.

K.H.Muhammad Nur misalnya mengungkapkan: "Manusia yang baik selalu menciptakan ketenteraman lahir dan batin di tengah-tengah masyarakat, memberikan contoh yang baik tanpa membedakan agama". Dalam konteks itu, lanjut Kiai yang belajar di Mekah selama 12 tahun ini, argumen-argumen dalam kitab-kitab Zabur, Taurat, dan Injil dapat menjadi rujukan bagi orang Islam sepanjang tidak bertentangan dengan Syariat Islam yang kita anut. Hal ini menunjukkan sikap toleransinya yang tinggi terhadap pemeluk agama lain demi terwujudnya kehidupan bersama.

Pendidikan berbasis akhlak dan mampu membangun tradisi yang baik itulah yang dicita-citakan oleh ulama, sebagaimana ditradisikan lewat pesantren. Itu pulalah yang dirasakan mengalami degradasi sebagai produk dari sistem pendidikan yang ada sekarang. Dalam konteks pengembangan ilmu berbasis akhlak inilah para ulama memandang perlunya dibina secara bersamaan melalui sistem pendidikan sifat-sifatfathanah (kepintaran/kognitif), amanah (kejujuran, keterpercayaan), shiddieq (selalu berusaha berada pada rel yang benar) dan tablig (menularkan kebaikan).

Untuk mencapai terbentuknya manusia yang baik itu diperlukan uswah hasanah atau keteladanan dari semua pihak yang berada pada posisi 
menentukan dalam proses pembentukan kepribadian. Ulama amat mengutamakan peran penting pemegang otoritas dalam masyarakat untuk menjadi teladan di masyarakat, terutama pemerintah dan pendidik. Mereka harus mampu menyelaraskan kata dan perbuatan.

Untuk itu, menurut ulama, diperlukan penataan ulang terhadap lembaga pendidikan, khususnya lembaga pendidikan Islam, agar dapat dibangun kembali model pendidikan dimana aspek akhlak atau moralitas bisa terbangun sebagai landasan bagi aspek intelektual atau pengetahuan anak-anak didik. Hal ini wajar bila ulama kemudian masih banyak memandang perlunya dipertahankan sistem kepesantrenan di satu sisi dan perbaikan sistem madrasah di sisi lain.

\section{Pandangan Ulama Tentang Madrasah}

Pada bagian ini ulama banyak menyoroti posisi dan kondisi madrasah sebagai model pendidikan Islam di Indonesia. Mereka melihat madrasah sebagai tumpuan harapan dalam upaya pencerdasan kehidupan umat Islam. Madrasah menjadi alternatif bagi model pendidikan yang dipandang dikotomis antara model pesantren di satu pihak dan pendidikan umum (sekuler) di pihak lain. Madrasah merupakan penggabungan keduanya. Dalam bahasa ulama, madrasah adalah model yang ideal, karena dapat menjalankan keseimbangan dunia dan akhirat.

Sebenarnya madrasah diarahkan pada pencapaian pendidikan yang integralistik. Secara yuridis, kebijakan ini dimulai sejak diberlakukan SKB (Surat Keputusan Bersama Tiga Menteri) 3 Maret, tahun 1975 tentang peningkatan mutu madrasah. Yang dimaksud madrasah menurut SKB tersebut ialah lembaga pendidikan yang menjadikan mata pelajaran agama Islam sebagai mata pelajaran dasar. Mata pelajaran yang diberikan sekurang-kurangnya 30 persen pelajaran agama di samping mata pelajaran umum 70 persen. Arahan ini diperkuat dengan masuknya pendidikan agama sebagai komponen dalam sistem pendidikan nasional yang ditetapkan dalam Undang-Undang nomor 2 Tahun 1989.

Ulama mengakui tujuan mulia pemerintah dengan keluarnya SKB 3 Menteri tersebut. Salah satu dampak positifhya adalah persamaan Madrasah Ibtidaiyah dengan Sekolah Dasar, Madrasah Tsanawiyah dengan Sekolah Menengah Pertama dan Madrasah Aliyah dengan Sekolah Menengah Atas. Pelaksanaan SKB 3 menteri tersebut bertujuan agar seluruh siswa pesantren mendapatkan ijazah yang diakui pemerintah untuk digunakan melanjutkan sekolah di lembaga pendidikan umum. 
Tabel 3: Pandangan Ulama Tentang Madrasah

\begin{tabular}{|c|c|c|}
\hline NO & NAMA ULAMA & Pandangan tentang Madrasah \\
\hline 1 & K.H.Muhammad Nur & $\begin{array}{l}\text { Kehadiran madrasah dilatarbelakangi } \\
\text { keseimbangan ilmu agama dengan ilmu } \\
\text { pengetahuan } \\
\text { umum sejalan dengan dalil Al Qur'an : berilah kami } \\
\text { kebahagiaan di dunia dan kebahagiaan di akhirat. }\end{array}$ \\
\hline 2 & Prof.Dr.KH. Sahabuddin & $\begin{array}{l}\text { Bentuk madrasah sudah cukup baik, namun masih perlu } \\
\text { pembenahan utamanya aspek kurikulum dan kualitas } \\
\text { gurunya. Idealnya minimal bergelar master. }\end{array}$ \\
\hline 3 & $\begin{array}{l}\text { Drs.K.H.Jamaluddin } \\
\text { Amien }\end{array}$ & $\begin{array}{l}\text { Pendidikan Islam bentuk madrasah jauh lebih maju dari } \\
\text { masa dahulu. }\end{array}$ \\
\hline 4 & Drs.K.H.Muh.Harisah As & Perlu dipertahankan tetapi disempurnakan kurikulumnya \\
\hline 5 & Drs.K.H.Bustamin Syarif & $\begin{array}{l}\text { Bentuk madrasah perlu ditingkatkan karena lebih } \\
\text { berorientasi duniawiyah bila anak-anak akan melanjutkan } \\
\text { ke sekolah yang lebih tinggi. }\end{array}$ \\
\hline 6 & Drs.H.Rizali Muh. Noor & $\begin{array}{l}\text { Terjadi perubahan dari wawasan semula, yaitu belajar dan } \\
\text { mendalami ajaran Islam, menjadi berimplikasi pada } \\
\text { kebutuhan hidup, status sosial, dan mendapatkan ijazah. }\end{array}$ \\
\hline 7 & Drs.KH.Ahmad Yamani & $\begin{array}{l}\text { Madarasah sudah memadai, tetapi lebih sarat muatan } \\
\text { pengetahuan umum dan menafikan pemantapan } \\
\text { pendidikan agama sebagai ciri khas suatu madrasah. }\end{array}$ \\
\hline 8 & Drs.K.H.M. Arif Siraj Lc & $\begin{array}{l}\text { Masyarakat tetap menganggap penting madrasah, namun } \\
\text { pendidikan madrasah setengah-setengah, tidak terfokus. }\end{array}$ \\
\hline 9 & S. Saggaf Aljufrie.MA & $\begin{array}{l}\text { Sistem madrasah membuat calon siswa menurun, kualitas } \\
\text { pelajaran agama kurang, luaran cenderung melanjutkan } \\
\text { ke sekolah lanjutan dan perguruan tinggi umum. }\end{array}$ \\
\hline 10 & Drs. Kaso & $\begin{array}{l}\text { Madrasah terkontaminasi dengan format pendidikan } \\
\text { umum. Madrasah tidak berbasis di pesantren hanya } \\
\text { berbeda sedikit pendidikan umum. }\end{array}$ \\
\hline 11 & $\begin{array}{l}\text { Drs. Zainul } \\
\text { Koesry.M.Ag }\end{array}$ & $\begin{array}{l}\text { Kurikulum madrasah terlalu berat karena adanya mata } \\
\text { pelajaran wajib dari pemerintah, dan keterbatasan SDM } \\
\text { (guru) serta fasilitas yang sangat terbatas. }\end{array}$ \\
\hline
\end{tabular}

Dengan aturan baru tersebut seluruh pesantren diminta untuk menyesuaikan dengan kurikulum Departemen Agama. Konsekuensinya, apabila pesantren tidak mengikuti kurikulum Departemen Agama, maka siswa pesantren tidak dapat diikutkan dalam ujian negara untuk mendapatkan ijazah.

Kurikulum madrasah, baik negeri maupun swasta yang berlaku secara nasional tertuang dalam Keputusan Menteri Agama Nomor 372 / 1993 tentang Kurikulum Pendidikan Dasar Berciri Khas Agama Islam (Madrasah Ibtidaiyah dan Madrasah Tsanawiyah) dan Keputusan Menteri Agama Nomor 373 / 1993 tentang Kurikulum Madrasah Aliyah.

Namun demikian, setelah berjalan lebih kurang dua dasawarsa, madrasah dinilai belum mampu memenuhi harapan ideal tersebut. 
Madrasah dinilai tidak fokus dan tanggung, la ila ha'ula wala ila ha'ula (tidak kesana tetapi tidak juga kesini), dalam arti luaran madrasah tidak mampu menguasai pengetahuan agama dan tidak juga pengetahuan umum. Banyak faktor dipandang sebagai penyebab kurang berfungsinya lembaga tersebut, antara lain yang paling dominan adalah kurikulum. Selain itu adalah faktor sumberdaya manusia, dan aspek metodologis.

Aspek kurikulum adalah satu di antara banyak hal, yang paling banyak mendapat sorotan ulama berkaitan dengan sistem madrasah. Ulama mengusulkan agar kurikulum madrasah menganut pola keseimbangan, yaitu minimal 50 persen pelajaran umum, dan 50 persen agama. Bahkan ada ulama yang menginginkan kurikulum madrasah terdiri dari 70 persen agama dan 30 persen umum. Pandangan lain yang lebih akomodatif adalah, tetap mempertahankan kurikulum akan tetapi guru-guru seharusnya diarahkan agar mampu memberikan pelajaran ekstra kurikuler keagamaan. Sebaliknya seorang guru bidang studi umum juga harus mampu mengaitkan setiap materi pelajaran dengan muatan keagamaan. Berikut ini pandang ulama terhadap kurikulum madrasah.

Tabel 4 : Pandangan Ulama Tentang Kurikulum Madrasah

\begin{tabular}{|c|c|c|}
\hline NO & NAMA ULAMA & $\begin{array}{c}\text { PANDANGAN TENTANG KOMPOSISI } \\
\text { KURIKULUM MADRASAH }\end{array}$ \\
\hline 1 & K.H.Muhammad Nur & Idealnya, 50-persen agama, 50 persen umum \\
\hline 2 & Prof.Dr.K.H.Sahabuddin & $\begin{array}{l}\text { Kurikulum madrasah tidak memadai Perlu dibalik yakni } \\
\text { porsi pelajaran agama } 70 \% \text { dan umum hanya } 30 \% \text {. }\end{array}$ \\
\hline 3 & Drs.K.H.Jamaluddin Amien & $\begin{array}{l}\text { Kurikulum madrasah perlu ada keseimbangan, paling } \\
\text { tidak jam pelajaran agama itu ditambah }\end{array}$ \\
\hline 4 & Drs.K.H.Muh.Harisah AS & Perbandingan $50 \%$ pelajaran umum, dan $50 \%$ agama \\
\hline 5 & Drs.K.H.Bustamin Syarif & $\begin{array}{l}\text { Kurikulum madrasah (70 \% umum: } 30 \% \text { agama }) \\
\text { sekarang sangat merusak masa depan masyarakat Islam. }\end{array}$ \\
\hline 6 & K.H.Raizali Muh. Noor & $\begin{array}{l}\text { Kurikulum madrasah kurang efektif, bahkan siswa akan } \\
\text { berada dipersimpangan, pelajaran umum tidak mantap } \\
\text { dan pelajaran agama tidak mapan. }\end{array}$ \\
\hline 7 & Drs.KH.Ahmad Yamani & $\begin{array}{l}\text { Tidak ada masalah, asal waktu yang sedikit mampu } \\
\text { dimanfaatkan secara optimal, dan guru bidang studi } \\
\text { umum mampu mengaitkan setiap pokok bahasan } \\
\text { dengan agama. }\end{array}$ \\
\hline 8 & S. Saggaf Aljufrie.MA & $\begin{array}{l}\text { Untuk ahli di bidang agama, maka kurikulum di } \\
\text { madrasah adalah } 70 \% \text { agama dan } 30 \% \text { umum. }\end{array}$ \\
\hline 9 & Drs. Kaso & $\begin{array}{l}\text { Madrasah versi non pesantren tidak ubahnya dengan } \\
\text { pendidikan umum, kurikulumnya tanggung. Idealnya } \\
\text { porsi pelajaran agama, } 70 \% \text { dan pelajaran umum } 30 \% \text {. }\end{array}$ \\
\hline 10 & $\begin{array}{l}\text { Drs. Zainul Romiz Koesry, } \\
\text { M.Ag }\end{array}$ & $\begin{array}{l}\text { Idealnya, perbandingan agama umum fifty-fifty. Tetapi } \\
\text { karena ketentuan perlu memanfaatkan waktu secara } \\
\text { efisien dan efektif dan mengisinya muatan lokal } \\
\text { agama. }\end{array}$ \\
\hline
\end{tabular}


Akan tetapi dalam realitas, polarisasi pendidikan masih sangat dirasakan. Integrasi kedua model pendidikan (umum dan agama) hanya diartikan sebagai pemberian porsi pelajaran umum dan agama secara berbarengan. Belum terjadi integrasi antara keduanya. Dalam arti materi pendidikan agama harus disajikan secara terpadu dengan materi pendidikan umum sehingga guru dituntut untuk mampu mengkolerasikan dan merelevansikan pendidikan agama dan pendidikan umum secara integral.

Jadi, menurut para ulama, esensi pendidikan yang integratif dalam sistem madrasah tidak tercapai karena yang ditenkankan adalah bentuk formalnya, yaitu kurikulum madrasah dengan perbandingan 70 persen pelajaran umum dan 30 persen pelajaran agama. Sedangkan, penekanan agar guru merelevansikan kedua pendidikan tersebut, tampaknya tidak jalan. Akibatnya, anak didik tidak akan mampu memahami ajaran agamanya secara mendalam. Bahkan setelah tamat, siswa akan berada di persimpangan. Pelajaran umum tidak mantap dan pelajaran agama tidak mapan. Secara metodoligis, mata pelajaran agama hampir bersifat teoritis saja. Bila muncul anggapan, bahwa dengan sistem pendidikan agama di madrasah tidak ada pengembangan materi agama.

\section{KESIMPULAN}

Fungsi ulama sebagai waratsah al-anbiyaa dan tabiatnya yang senantiasa takut (khasyyah) kepada Allah menjadi faktor pendorong bagi mereka untuk selalu tampil mengaplikasikan fungsi utama mereka dalam berbagai kegiatan di kalangan ummat, yang secara tradisional terfokus pada bidang dakwah, pendidikan, dan pelayanan kepada ummat dalam pelaksanaan syariat Islam.

Ulama adalah sedikit dari umat Islam yang amat dibutuhkan kehadirannya di tengah masyarakat yang terus berubah sementara ulama sendiri semakin langka. Dalam kelangkaan itulah ulama menanggung beban berat untuk menjaga aqidah dan moral umat terutama melalui pendidikan Islam baik formal maupun nonformal.

Melalui lembaga pendidikan Islam ulama menfokuskan aktivitasnya guna mencapai tujuan pencapaian manusia ideal atau insan kamil dan masyarakat ideal, yaitu baldatun thayyibah warabbun ghofuur. Ulama menyadari bahwa instrumen utama mencapai insan kamil dan baldatun thayyibah adalah melalui pendidikan sepanjang hidup manusia. 
Untuk membangun manusia yang ideal ulama melihat perlunya dibangun pendidikan berbasis akhlak. Pembangunan pendidikan berbasis akhlak ini pada gilirannya menuntut adanya pengembangan tradisi yang baik di dalam masyarakat. Wujud tradisi yang baik berdasarkan moralitas agama tersebut dapat dilihat pada pengembangan budaya yang santun, damai untuk semua kalangan. Selain kemampuan membangun dimensi kecerdasan (fathonah) dimensi terpenting lainnya adalah dimensi pentradisian melalui kemampuan memberikan contoh yang baik dari kalangan pemegang otoritas yang berpengaruh, terutama pemerintah dan kalangan pendidik.

Dalam konteks itulah ulama melihat lembaga pendidikan Islam kini mengalami degradsi dimata umat. Model pendidikan dalam bentuk madrasah yang pada awalnya dianggap ideal karena merupakan alternatif dari adanya dikotomi tajam antara pendidikan agama (pesantren) dan pendidikan umum ternyata mengecewakan. Madrasah telah melahirkan luaran-luaran setengah jadi dan tidak jelas orientasinya. Lembaga pendidikan pesantren yang sudah terlanjur mengikuti pola madrasah tersebut ikut menerima dampaknya. Lembaga yang pernah berjasa sebagai wadah bersemainya calon dan kader ulama sekarang mulai terasa kemandulannya. Hasilnya dapat dilihat pada kelangkaan ulama.

Pengalaman tersebut menjadi dasar yang amat berharga untuk kembali melakukan peninjauan terhadap sistem pendidikan Islam. Kurikulum madrasah dipandang perlu ditinjau kembali komposisi dan sistemnya. Selain itu perlu pendekatan integralistik dalam pengajaran agama dan umum di madrasah. Hal itu diarahkan pada pembentukan kepribadian dan kecerdasan secara seimbang. 


\section{DAFTAR PUSTAKA}

Abdullah, T.1987.l996.Agama dan Perubahan Sosial. Rajawali Pers, Jakarta.

Azra, A. 1994. Jaringan Ulama Timur Tengah dan Kepulauan Nusantara Abad XVII dan XVIII. Mizan, Bandung.

Badrun, P. dan Rahman, A. 1996. Apresiasi Kelekturan Bagi Aparat Sara di Sulawesi Selatan. Hasil Penelitian tidak diterbitkan. Balai Penelitian Lektur Keagamaan Ujung Pandang, Ujung Pandang.

Baghdadi, A.al. 1994. Ulama dan Penguasa Di Masa Kejayaan dan Kemunduran (diindonesiakan oleh Muhammad Abbas dan Usman Hatim). Gema Insani Press, Jakarta.

Beatty, A. 2001. Variasi Agama di Jawa : Suatu Pendekatan Antropologi (diterjemahkan olehAchmad Fedyani Saefuddin). PTRaja Grafindo Persada, Jakarta.

Benda, H.J. 1958. The Crescent and The Rising Sun; Indonesian Islam Under the Japanese Occupation 1942-1945. W. van Horve Ltd., The Hague and Bandung.

Boland, B.J. 1971. The Struggle of Islam In Modern Indonesia. The Hague - Martinus Nijhoff, Leiden.

Bruinessen, M.van. 1999. Rakyat Kecil, Islam dan Politik. Yayasan Bentang Budaya, Yogyakarta.

Bukhariy, Imam Abi Abdullah Muhammad bin Ismail, al. Tanpa tahun. Shahih Bukhari (Jilid I). Dar al-Fikr, Beirut.

Conger, J.A. 1997. Pemimpin Karismatik (diterjemahkan oleh Anton Adiwiyoto). Binarupa Aksara, Jakarta.

Eickelman, D.F. dan James, P. 1998. Ekspresi Politik Muslim (diterjemahkan oleh Rofik Suhud). Penerbit Mizan, Bandung.

Effendi, B. 1990. An Nuqayah : Gerak Transformasi Sosial di Madura. P3M, Jakarta .

Geertz, C. 1960. The Javanese Kijaji : The Changing Role of a Cultural Broker. Comparative Studies in Society and History, Volume 2, Issue2. 
Hefner, R.W.2000. Islam, Pasar, Keadilan (dijerjemahkan oleh Amiruddin dan Asyhabuddin). LKiS, Yogyakrta.

Horikoshi, H. 1987. Kyai dan Perubahan Sosial. Perhimpunan Pengembangan Pesantren dan Masyarakat (P3M), Jakarta.

Kartodirdjo, S.(ed.). 1991. Elite dalam Perspektif Sejarah. LP3ES, Jakarta.

Khuluq, L. 2000. Fajar Kebangkitan Ulama, Biografi K.H.Hasyim Asy'ari .LKiS. Yogyakarta.

Lapidus, I.M. 1989. A History of Islamic Societies. Cambridge University Press, Cambridge.

Mansurnoor, I. A. 1990 Islam in an Indonesian World, Ulama of Madura. Gadjah Mada University Press, Yogyakarta.

Steenbrink, K. A. 1986. Pesantren Madrasah Sekolah. LP3ES, Jakarta.

Zuhri, Saifuddin. 1981 Kaleidoskop Politikdi Indonesia. Jilid 3. Jakarta : Gunung Agung 